\title{
Review
}

\section{Selenium behavior in the soil environment and its implication for human health}

\section{Comportamento de selênio no solo e sua implicação para a saúde humana}

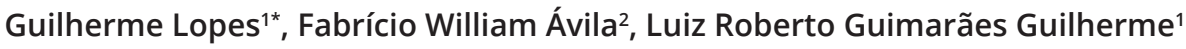

\author{
${ }^{1}$ Universidade Federal de Lavras/UFLA, Departamento de Ciência do Solo/DCS, Lavras, MG, Brasil \\ ¿Universidade Estadual do Centro-Oeste/UNICENTRO, Guarapuava, PR, Brasil \\ ${ }^{*}$ Corresponding author: guilherme.lopes@dcs.ufla.br \\ Received in July 23, 2017 and approved in October 30, 2017
}

\begin{abstract}
Selenium (Se) is an important element that was discovered in 1817, and since the 1960s, it has been regarded as an essential micronutrient for both animals and humans, playing among other functions a relevant role in the antioxidant system of mammals. Inadequate blood Se levels in the human body is a well-known concern in many parts of the world. This malnutrition problem is often due to Se-poor diet, probably as a result of the low Se availability in soils where crops are growing. Nowadays, it is known that not only the total content, but also the inorganic and organic forms of Se contained in foods are important for human nutrition. However, paradoxically some regions of the world present high Se levels in soils causing several functional disorders and diseases in people who live in seleniferous areas. As essential micronutrient, Se should be supplied in controlled amounts to avoid harmful effects. Therefore, taking into account the importance of the soils as a way to ensure the adequate Se supply for the population, this review has dealt with Se behavior in soil environment (e.g., Se forms and adsorption and desorption reactions) and its relevance for the human health. As a final message, the further understanding of Se behavior in soils to predict its availability for crops in different systems will be a significant approach in future studies to establish forms and safe doses of Se to be added in fertilizers. Agronomic and genetic biofortification of staple crops with Se has been suggested as an important tool to improve Se intake by population in Se-poor sites.
\end{abstract}

Index terms: Essential micronutrient; Se adsorption; Se availability; biofortification; human nutrition.

\begin{abstract}
RESUMO
O selênio (Se) é um elemento importante que foi descoberto em 1817 e reconhecido como elemento essencial para os humanos e animais desde os anos 60. Esse elemento apresenta, dentre outras funções, papel relevante no sistema antioxidante dos mamíferos. Níveis inadequados de Se no corpo humano tem sido uma preocupação bem conhecida em muitas regiões do mundo. Esse problema de desnutrição com Se ocorre frequentemente devido a dietas pobres nesse elemento, o que provavelmente tem relação com a baixa disponibilidade de Se nos solos onde as culturas agrícolas estão sendo cultivadas. Atualmente, sabe-se que, além da quantidade de Se contida nos alimentos, sua forma (e.g., inorgânica ou orgânica) é importante para a nutrição humana. Apesar da deficiência de Se ser um problema em alguns locais, algumas regiões do mundo apresentam níveis altos de Se nos solos, causando várias desordens e doenças nas pessoas que moram nestas áreas consideradas seleníferas. Sendo um elemento essencial, o Se deve ser suprido em quantidades adequadas para evitar efeitos prejudiciais. Assim, levando-se em consideração a importância dos solos como um meio para garantir o suprimento adequado de Se para a população, esta revisão tem abordado o comportamento do Se no ambiente do solo (e.g., formas de Se e reações de adsorção e dessorção) e sua relevância para a saúde humana. Como mensagem final, a compreensão do comportamento de Se em solos visando prever sua disponibilidade para as culturas agrícolas em diferentes sistemas será uma abordagem significativa em estudos futuros para estabelecer formas e doses seguras de Se para serem adicionadas em fertilizantes. A biofortificação agronômica, aliada a biofortificação genética, de culturas básicas com Se tem sido sugerida como importante ferramenta para melhorar a ingestão de Se pela população que vive em locais onde os solos são pobres em Se.
\end{abstract}

Termos para indexação: Elemento essencial; adsorção de Se; disponibilidade de Se; biofortificação; nutrição humana.

\section{INTRODUCTION}

The element selenium (Se) is placed in the subgroup VIA of the periodic table (called also chalcogen group). It was discovered in 1817 by Swedish chemist Jons Jakob Berzelius, who named the new element from the Greek word 'Selene', meaning Goddess of the Moon (Terry et al., 2000). Selenium is widely used in industry for the manufacture of several products, such as semiconductors, rectifiers, photovoltaic cells (because of its ability to convert light energy into electrical energy), corrosion-resistant alloys, pharmaceutical substances, and 
pigments (red and orange color) for paints, ceramics, and glass-making process (Mehdi et al., 2013).

However, global interest of scientific studies involving Se has been significantly raised from the discovery of its essential role for animal body cells in the 1950s (Schwarz and Foltz, 1957). From the 1960 s, several publications have pointed out clearly the essentiality of Se for human health (FairweatherTait, 2011; Rayman, 2012; Riaz and Mehmood, 2012; Alfthan et al., 2015). Inadequate intake of Se, added with iron (Fe), zinc ( $\mathrm{Zn})$ and iodine (I), vitamin A and vitamin B-12, become a malnutrition problem in a large proportion of the world' population (Combs, 2000; White and Broadley, 2009; Miller and Welch, 2013). The dietary Se intake in a region is influenced greatly by the food Se contents, which in turn is closely linked with the availability of the element in the environment, especially in the soil (Pietinen et al., 2010; FairweatherTait et al., 2011; Mehdi et al., 2013). Thus, researches that have addressed the question of the geochemical behavior of Se in soils has increased in the last decades. In this context, this review has focused on Se behavior in soil environment and its effects on human Se nutrition. Therefore, it was addressed the importance of increasing available Se contents in soils in order to find adequate Se contents in edible parts of agricultural crops, which may contribute to enhance the human Se intake.

\section{EVOLUTION OF SELENIUM RESEARCH OVER THE DECADES SINCE 1950}

The number of publication or documents found in literature involving the element selenium from the decade of 1950 until 2017 is shown in Figure 1. First at all, note that there are several years that Se has been studied, taking into account the presence of documents in the decade of 1950 (Figure 1A). However, it has to be stated that when the keyword "selenium" is combined with other terms (e.g., soil, human, plant, and fertilizer), no documents were found in the decade of 1950.

The researches with $\mathrm{Se}$ and its interaction with other compartments, such as soil, plant, human, and fertilizer have been expanded from the decade of 1950 to the recent days, especially researches involving $\mathrm{Se}$ linked with humans, as reported in Figure 1 (from letter A to I). This may be related to the role and importance of Se in human health, and as a result, several researches evaluating the effect of Se in human health have been conducted thereafter (Yang et al., 1983; Ip and Ganther, 1990; Ip et al., 2000; Dong et al., 2001; Medina et al., 2001; Goldhaber, 2003; Ryan-Harshman and Aldoori,
2005; Lee et al., 2006; Rayman, 2012; Riaz and Mehmood, 2012).

As showed in Figure 1, significant increase in the number of scientific literature in the decade of 1990 has been occurred. This fact may be attributed, among other factors, due to the development of sensitive techniques for the determination and quantification of elements in different compartments, such as in soil, fertilizer, plant, and human tissues.

\section{SELENIUM IN ENVIRONMENT: FOCUS ON ITS BEHAVIOR IN SOILS}

Selenium (Se) in soils depends of the geological parent material, among other factors. It is known that sandy soils have lower Se contents compared to organic and calcareous soils (Kabata-Pendias, 2011; El-Ramady et al., 2014). The presence of elements, such as Se, in the soil is important because plants take up elements from the soil, actually, from soil solution. Thus, Se contents in plants are related with Se contents of the soils where plants grow. In the case of Se, it is well known its essentiality for animals and humans, yet it does not occur for plants (Christophersen et al., 2013; Rayman, 2012; Riaz and Mehmood, 2012). However, it has to be mentioned that Se can also be toxic to organisms in higher concentrations, showing essential to toxic characteristics in a narrow concentration range (Lenz and Lens, 2009). Therefore, efforts have been addressed to understand Se behavior in the environment, especially which factors may alter its availability and mobility in soils, thus allowing to prevent Se deficiency or toxicity.

Selenium exists in different oxidation states, such as selenate $\left(\mathrm{Se}^{6+}\right)$, selenite $\left(\mathrm{Se}^{4+}\right)$, elemental selenium $\left(\mathrm{Se}^{0}\right)$ and selenide $\left(\mathrm{Se}^{2-}\right)$. Besides other variables, such as clay and organic matter contents, the major factors that control Se forms in soil are $\mathrm{pH}$ and redox potential (Eh) (El-Ramady et al., 2014; Kabata-Pendias, 2011). In natural soil conditions, selenate and selenite are the main inorganic Se forms. Selenate predominates in alkaline soils and has higher mobility than selenite, which commonly occurs in neutral or acid soils and is easily sorbed on oxyhydroxides (Kabata-Pendias, 2011).

Based on the above statements, a high Se mobility might be expected in soils of high $\mathrm{pH}$ and Eh while soils with high contents of oxyhydroxide, clay, and organic matter lead to a low Se mobility. In terms of Se oxidation states as a function of Eh, Elrashidi et al. (1987) reported that Se may occurs as $\mathrm{Se}^{+6}, \mathrm{Se}^{+4}$, and $\mathrm{Se}^{-2}$ when the values of Eh are, respectively, higher than $400 \mathrm{mv}$, in the range of 200-400 mv, and lower than $200 \mathrm{mv}$. A good description 
(A) "selenium"

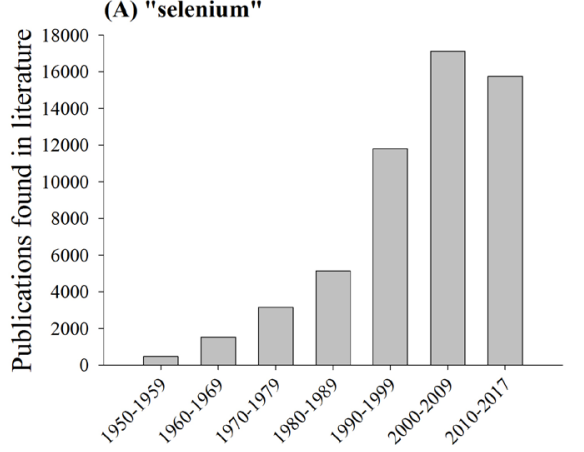

(D) "selenium" and "plant"

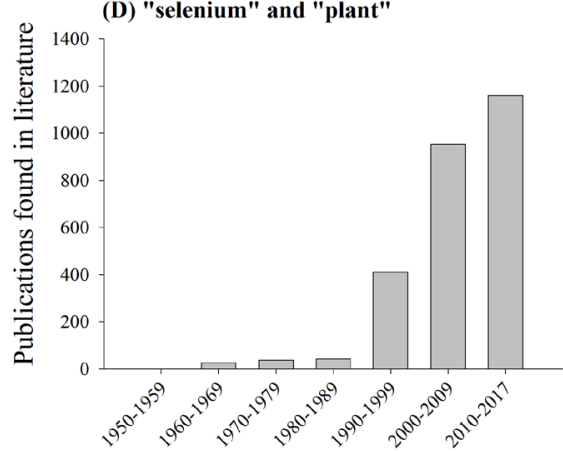

(G) "selenium" and "human" and "plant"

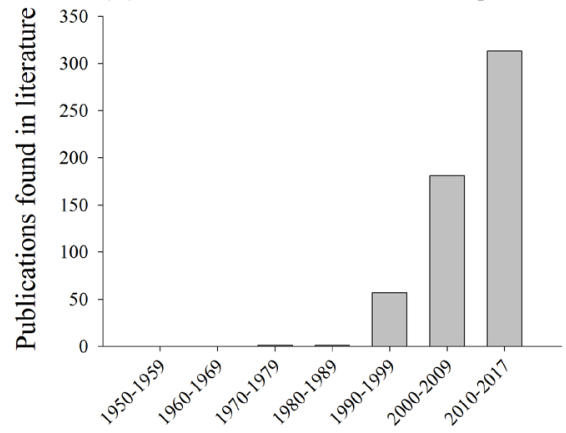

(B) "selenium" and "soil"

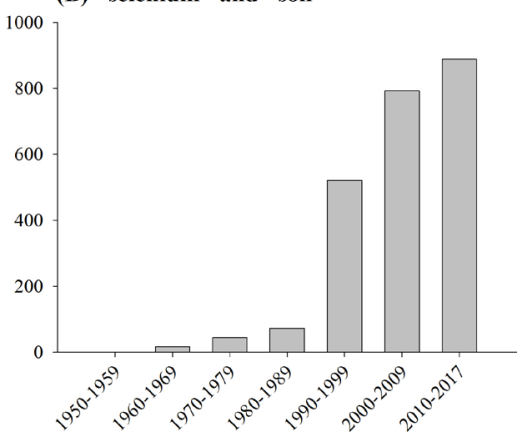

(E) "selenium" and "soil" and "human"

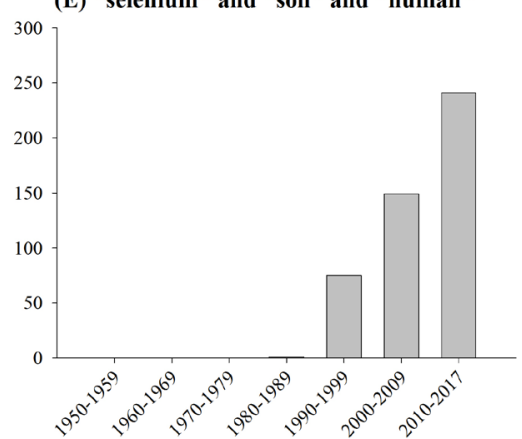

(H) "selenium" and "fertilizer"

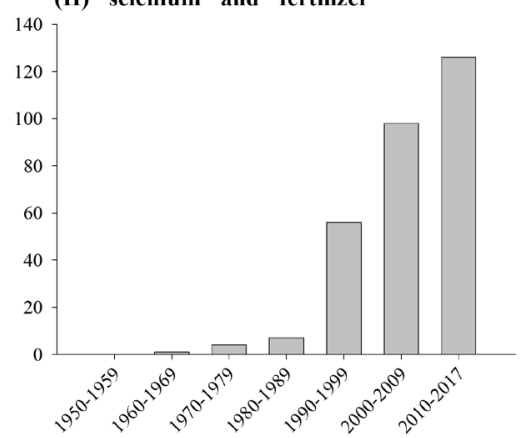

(C) "selenium" and "human"

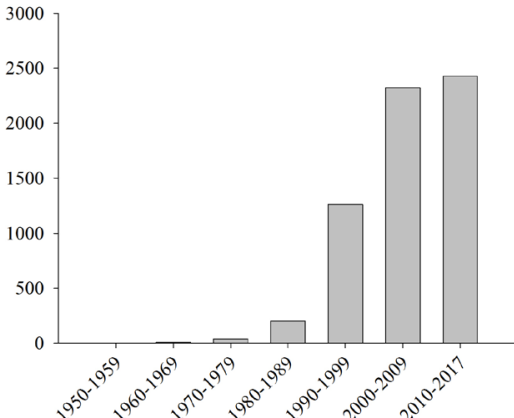

(F) "selenium" and "soil" and "plant"

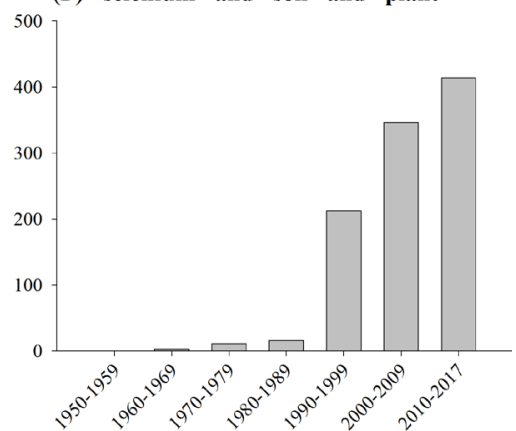

(I) "selenium" and "soil" and "fertilizer"

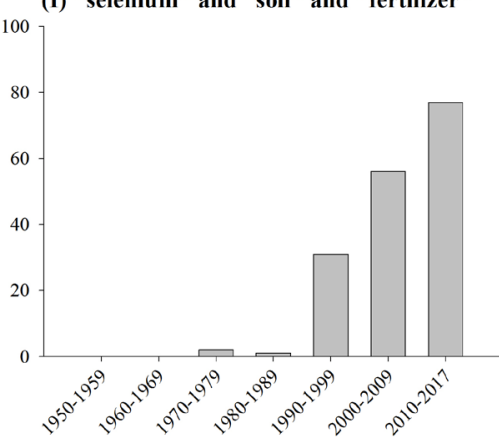

Figure 1: Number of scientific publications or documents found in literature involving the element selenium from the decade of 1950 until 06/12/2017 (source: Web of Science database).

about Se forms as related to change $\mathrm{pH}$ and Eh as well as varying organic matter and $\mathrm{Fe} / \mathrm{Al}$ oxyhydroxide contents can be found elsewhere (Nakamaru and Altansuvd, 2014; Tolu et al., 2014).

Therefore, Se bioavailability in soils depends not only of the total Se concentration but also it varies as a function of the predominant Se species that are present in the soil. In this context, Se forms may affect Se mobility. Thus, studies evaluating the speciation of Se have received attention in the literature (Martens and Suarez, 1997; Li et al., 2010). In this context, after the advent of synchrotron facilities, one easy way currently available to measure oxidation states of different elements (e.g., As, Fe, Mn, $\mathrm{Cr}$, and others), including $\mathrm{Se}$, is using the technique termed as X-ray Absorption Spectroscopy (XAS). Such technique is one of the most widely used synchrotronbased technique (Sparks, 2011) and the oxidation states of different elements have been widely assessed using the XANES (X-ray absorption near edge spectroscopy) portion of the spectrum (Vodyanitskii, 2013). It has to be stated that XAS technique has a great advantage of using micro-volumes of soil samples with negligible sample 
preparation, thus allowing to measure an undisturbed sample (Kelly et al., 2008).

\section{Selenium abundance in rocks and soils}

The abundance of Se in the Earth's crust is very low, estimated as $0.05-0.10 \mathrm{mg} \mathrm{kg}^{-1}$, as a result of Se be easily volatilized during crust formation (Ryan and Dittrick, 2000). However, geographical distribution of $\mathrm{Se}$ is highly variable. Worldwide Se contents in eruptive, metamorphic, and sedimentary rocks are 0.01-7.0, 0.16.5, and 0.01-7.0 $\mathrm{mg} \mathrm{kg}^{-1}$, respectively (Who, 1987). In spite of the wide range of variation of individual values, higher Se concentrations can be found in the sedimentary rocks such as limestones $(<0.1-7.4 \mathrm{mg}$ $\left.\mathrm{kg}^{-1}\right)$, sandstones $\left(<0.1-1.7 \mathrm{mg} \mathrm{kg}^{-1}\right)$, and shales $(<0.1-$ $12.0 \mathrm{mg} \mathrm{kg}^{-1}$ ) (Connor and Schaklette, 1975). Very high Se contents have been reported in some phosphate-rich rocks (Robbins and Carter, 1970), marine or black shales (Ryan and Dittrick, 2000), coals (Coleman et al., 1993), and other rocks enriched with organic carbon. Some components of sulphide mineral deposits can also be source of Se to the environment, whereas elemental $\mathrm{Se}^{0}$ is rarely mentioned in literature (Fordyce, 2007).

The parent rock has a large influence on the Se content found in soils. Average Se concentration in soils worldwide is relatively low $\left(0.4 \mathrm{mg} \mathrm{kg}^{-1}\right)$ (Kabata-Pendias, 2011). As in Earth's crust, Se occurrence in soils is very uneven in the geographical distribution. Although igneous volcanic rocks are commonly poor in Se (Fordyce, 2005), some volcanic soils may be 1-2 orders of magnitude higher in Se contents than the world average. High-temperature gases with high Se content (due to its volatility) are released during eruptions. Interactions between volatile elements and volcanic ashes that occur within the eruption plume originate tuffs with high Se concentration, which play an important role in the formation of selenosis areas, such as Keterson reservoir in the USA and the Ziyang Country in China (Floor and Román-Ross, 2012). In fact, it has been known that after volcanic eruptions, Se concentrations in pasture may significantly raise (Cronin et al., 1997).

The amount and the geochemical mobility of the Se deposited by volcanic ashes depend on the eruption features, particle size-fractions, temperature within the plume, soil biological reactions, and climate condition such as wind and humidity (Floor and Román-Ross, 2012). Selenium adsorption capacity on soil components is fundamental to define the mobility and bioavailability (amount taken up into plants and animals) of this element in the environment. On the other hand, Se sorption properties in soils are influenced by several factors such as $\mathrm{pH}$, soil mineralogy and texture, organic matter content, Se chemical form, redox condition, and interactions with other ions (Fordyce, 2007). In general, volcanic soils can have high Se concentrations, but sometimes with low bioavailability (Floor e RománRoss, 2012; Tolu et al., 2014). For example, some regions in the world have volcanic soils with high $\mathrm{Se}$ contents (Andolosols), presenting a historic of diseases related to the Se deficiency in humans due to the low bioavailability of this element in soil (Rayman, 2000; Floor et al., 2009).

Organic carbon-rich soils tend to present higher Se contents because of microorganisms and vegetable waste (Se-accumulating plants) that accumulate Se (Saikiet et al., 1993; Shand et al., 2012). Soil organic matter has an important role in the Se dynamic in the soil-plantatmosphere system. Associations between organic matter fraction and mineral phase (especially oxyhydroxides), resulting in organo-mineral associations, may affect the properties of the soil in terms of Se adsorption capacity (Floor and Román-Ross, 2012; Tolu et al., 2014). Most part of inorganic Se can be interacting with soil organic matter, which may be (or not) bioavailable in function of the sort of established interactions, especially those with humic substances. It seems that the Se bioavailability in soil is higher when this element is associated with fulvic acids than with humic acids (Qin et al., 2012). In addition to interactions between inorganic-Se and humic substances, plants and microbial processes may also immobilize inorganic Se (Tolu et al., 2014).

In several regions in the world, soils present low Se availability, resulting in diseases and disorders related to Se deficiency in human organism (Combs, 2001; Mehdi et al., 2013). Selenium deficient soils are found in UK, Australia, central Siberia, New Zealand, Thailand, Africa, Finland, Turkey, Nepal, northeast to south central of China, Denmark, and parts of Bangladesh and India, among others (Rahman et al., 2013; Yasin et al., 2015). Most soils of the tropical zones have low Se concentrations (Sillanpää and jansson, 1992; Christophersen et al., 2013; Gabos et al., 2014a; Matos et al., 2017). In this context, Table 1 shows some few examples of low Se contents in different regions worldwide. As can be seen, the average of Se contents found in these regions/countries are all low, being considered Se-deficient soils. These areas with low Se contents in soils may produce food with Se concentration that are not enough to guarantee the ingestion of Se in adequate amounts by animals and humans. 
Table 1: Selenium contents in soils of different regions worldwide.

\begin{tabular}{ccccc}
\hline \multirow{2}{*}{ Location (region) } & $\begin{array}{c}\text { Number of soil } \\
\text { samples analyzed }\end{array}$ & \multicolumn{2}{c}{ Se contents $\left(\mathrm{mg} \mathrm{kg}^{-1}\right)$ - Topsoil } & \multirow{2}{*}{ Reference } \\
\cline { 4 - 5 } & 539 & $0.14-0.70$ & 0.33 & Termmerman et al. (2014) \\
Belgium & 180 & $0.05-2.80$ & 0.51 & Yamada et al. (2009) \\
Japan & 22 & $0.20-1.00$ & 0.50 & Nakamaru et al. (2006) \\
Japan & 250 & $0.03-1.42$ & 0.23 & Zhang et al. (2008) \\
China (Guangdong Province) & 144 & $0.12-0.88$ & 0.43 & Fordyce et al. (2010) \\
Scotland & 490 & $0.003-2.7$ & 0.43 & Pérez-Sirvent et al. (2010) \\
Spain (Murcia) & 50 & $0.015-0.43$ & 0.058 & Bradford et al. (1996) \\
United States (California) & 445 & $0.01-4.62$ & 0.25 & Chen et al. (1999) \\
United States (Florida) & 58 & $<0.08-1.61$ & 0.19 & Gabos et al. (2014a) \\
Brazil (São Paulo) & 12 & $<0.30-5.97$ & 1.09 & Matos et al. (2017) \\
Brazil (Jequitinhonha Valley) & & &
\end{tabular}

On the other hand, other regions (called seleniferous areas) have the soil and water highly enriched with Se, sometimes in toxic levels to human and animal health ( soil Se content $>2000 \mathrm{mg} \mathrm{kg}^{-1}$ ). Australia, the USA, Ireland, China, and India are examples of countries that present large areas where Se bioavailability in soils are high enough to cause toxicity (Bajaj et al., 2011; Eiche, 2015). In seleniferous areas, Se is reported to be a chemical element with environmental problems.

\section{Sorption behavior of selenium in soils}

Sorption behavior of Se depends on, among other factors, Se speciation. As mentioned early, selenate is less sorbed than selenite, thus, the last form is strongly adsorbed on solids, such as $\mathrm{Fe} / \mathrm{Al}$ oxyhydroxides, having low mobility in soils. Several studies have showed that selenite is adsorbed much more strongly than selenate on different solid surfaces, such as manganese oxide (Saeki et al., 1995), hydroxyapatite (Monteil-Rivera et al.; 2000), and soils (Eich-Greatorex et al., 2010). The difference in adsorption behavior of selenate and selenite reflects different Se contents that are plant-available, being the selenate much more phytoavailable.

In terms of the adsorption mechanisms, selenate forms mainly outer-sphere complexes, which is bound by non-specific anion exchange, whereas selenite is bound by ligand exchange, creating inner-sphere complexes that are not reversible (McBride, 1994). In the case of selenate, besides bound by outer-sphere complex, which is its predominant adsorption mechanism, researches have also shown contributions of inner-sphere complexes, generating a mixture of outer- and inner-sphere surface complexes, as reported on iron oxides and hydroxides (Peak and Sparks, 2002) and on maghemite (Jordan et al., 2013).

Selenate and selenite may compete with organic acids as well as with other anions, such as phosphate and sulfate for soil adsorption sites. This fact is relevant for agroecosystems, particularly, for tropical soils taking into account that these soils usually receive high amounts of phosphate and sulfate, which come up from agricultural products applied on soils, such as fertilizers and gypsum. Because Se can be in several interactions in the environment, its sorption behavior differs among soils, where the soil management or production systems are different. Therefore, local researches evaluating variables that may alter the behavior of Se in a particular environment need to be better understood. For example, Øgaard et al. (2006) reported that cattle manure affects selenium behavior in soils, decreasing the sorption of both Se species, selenate and selenite.

There are studies in literature showing the effect of phosphate under Se adsorption. Most of these studies showed that Se become more plant available following phosphate addition, i.e., Se sorption decreases as phosphate increases, which is well reported for Japanese soils (Nakamaru et al.; 2006; Nakamaru and Sekine, 2008). It has to be mentioned that this trend is more pronounced for selenite than selenate. This occurs due to chemical similarities between phosphate and the selenite anion (Eich-Greatorex et al., 2010), while the anion selenate tends to compete with sulfate. These information may assist explain the results found by Nakamaru and Sekine (2008), where it was verified that selenite sorption did not change after an increase in the sulfate concentration. 
Few studies evaluating Se sorption on Brazilian soils may be found in literature, such as the cited studies (Mouta et al., 2008; Abreu et al., 2011; Gabos et al., 2014b). Most of these studies evaluated Se sorption using high Se concentration added in solution, which is valuable. However, researches to understand adsorptiondesorption reactions of Se in Brazilian soils using low $\mathrm{Se}$ concentration to reflect the true situation (e.g., possible doses required for biofortification of crops) are deficient, being necessary to build up database regarding $\mathrm{Se}$ behavior in terms of its retention in Brazilian soils. Such studies are relevant and the basic ideas and some results have been presented in a paper recently published by our research group (Lessa et al., 2016). Basically, these recent studies were carried out using some selected soils from the Brazilian Cerrado and it was found in the first results that soil cultivation tend to affect $\mathrm{Se}$ (VI) adsorption on Brazilian tropical soils.

The effect of soil cultivation upon selenate adsorption may be attributed to the presence of competing anions, such as sulfate and phosphate, in higher contents in cultivated soils than in uncultivated ones. This allows to point out that the uncultivated soils adsorb much more Se compared to the cultivated soils, as reported for the studied soils by Lessa et al. (2016).

\section{IMPORTANCE OF SELENIUM IN HUMAN HEALTH}

Selenium (Se) is a trace element playing an essential role in human and animal health. It is necessary for the synthesis of the amino acid selenocysteine, which is involved in the formation of approximately 25-35 proteins (called selenoproteins) that are critical in mammal metabolism (Rayman, 2012; Oliver and Gregory, 2015). Examples of selenoproteins include the glutathione peroxidases (with antioxidant functions), thioredoxin reductases (oxidoreductases that act on disulfide reduction system), iodothyronine deiodinases (responsible for synthesis and metabolic regulation of thyroid hormone) methionine-R-sulfoxide reductase (a zinc-containing selenoprotein), selenophosphate synthetase 2 (synthesis of the active $\mathrm{Se}$ donor selenophosphate), 15-kDa selenoprotein (thioredoxin-like fold ER-resident proteins), and selenoproteins H, I, M, T, V, and W (Rayman, 2012; Labunskyy et al., 2014).

Selenium deficiency in the human organism has been linked with thyroid gland dysfunctions, irreversible brain damage, peripheral vascular diseases, chronic and degenerative osteoarthropathy (Kashin-Beck disease), impaired immune response to viral infections (such as measles, hepatitis, influenza and HIV/AIDS), male infertility, pre-eclampsia in women, heart diseases and higher risk for different types of cancers (Combs, 2000; Pilon-Smits and Quinn, 2010; Davis et al., 2012; Fairweather-Tait et al., 2011; Rayman, 2012; Riaz and Mehmood, 2012; Cardoso et al., 2015). Institute of Medicine of the USA National Academy has established a RDA for Se of $55 \mu \mathrm{g} \mathrm{day}^{-1}$ for adults while the tolerable upper intake for adults is $400 \mu \mathrm{g} \mathrm{day}^{-1}$ (Bendich, 2001). This safe range of dietary intakes of $\mathrm{Se}$ is considered narrow (Tan et al., 2002). Although Se deficiency in the animal and human body leads to various diseases and disorders, an excessive Se intake is also capable of causing adverse effects to health (Yang et al., 1983; Goldhaber, 2003; Aldosary et al., 2012; Riaz and Mehmood, 2012).

Besides the selenoproteins, non-protein organic forms of Se have been also shown to have important benefits to human health. Recently, particular attention has been given to the anticarcinogenic effects of some methylated organic compounds of Se. Although there are studies reporting on the chemopreventive properties of some non-methylated organic forms of Se (Ryan-Harshman and Aldoori, 2005; Rayman, 2012; Riaz and Mehmood, 2012), several researches have been able to demonstrate a potent anticancer activity of monomethylated Se forms, especially Se-methylselenocysteine and $\gamma$-glutamyl-Semethylselenocysteine (Ip and Ganther, 1990; Ip et al., 2000; Dong et al., 2001; Medina et al., 2001; Lee et al., 2006; Wang et al., 2009).

\section{HOW TO INCREASE SELENIUM INTAKE BY HUMANS}

As aforementioned, some regions around the world have soils with high Se contents (seleniferous soils), which may cause several diseases in local population because of the excessive intake of this element (Swanson et al., 1990; Yang et al., 1983; Goldhaber, 2003; Riaz and Mehmood, 2012). However, taking into account that available Se contents in soils is considered low in many parts of the world, it is expected that the population in these regions has not obtained the necessary Se amount as the dietary intake recommendation. It was estimated that between 0.5 and 1.0 billion of people in the world have deficiency in $\mathrm{Se}$ (Combs, 2001). In Brazil, the evidences of insufficient Se intake by population are high (Ferreira et al., 2002; Maihara et al., 2004), due to the most Brazilian soils used in the agriculture have low Se content (Gabos et al., 2014a; Matos et al., 2017). 
In this context, some actions in order to increase Se ingestion by animals and humans have taken place, such as the use of supplements (capsules containing Se and other minerals) or enrichment of foods with Se during industrial processing. Researches have pointed out that the use of supplements is somewhat uncertain in terms of efficiency due to the Se forms added in commercial supplements, as well as because the supplements are usually unevenly distributed among different population groups (Pietinen et al., 2010). In addition, Aldosary et al. (2012) and Morris and Crane (2013) reported several cases of $\mathrm{Se}$ intoxication in people due to the intake of these supplements. Industrially fortified foods and supplements mostly contain inorganic Se forms (selenate and/or selenite). It is well known that the $\mathrm{Se}$ speciation significantly affects the potential benefits of this element to mammal health, being the organic Se forms (selenocysteine and/or selenimethionine) the most effective bioavailable Se species for the animal and human nutrition (Thomson, 2004; Fairweather-Tait et al., 2010). Studies have reported that inorganic Se forms have lower bioavailability in the human organism and also present higher risk of toxicity by excessive intake (Barceloux, 1999; Finley, 2006; Thomson, 2004; Veatch et al., 2005).

In general, Se-containing supplements and/or Se-fortified foods for industrial processing are still little accessible to the population of lower socio-economic status (Pietinen et al., 2010). In this way, the plants play a key role to include Se in food chain. They may take up the Se in its inorganic forms predominant in the environment (in general, selenate and selenite anions), and convert them to functional organic forms (PilonSmits and Quinn, 2010).

Unlike mammals, Se is not a plant nutrient although is considered a beneficial element that have the potential to influence the antioxidant activity systems of the higher plants (Pilon-Smits and Quinn, 2010; Ramos et al., 2010). However, excessive content of Se in plant tissue may be detrimental for most crops (Terry et al., 2000). The ability of plants to accumulate Se (without causing toxicity) varies among species and even among cultivars of the same species. Most agricultural plants are classified as Se non-accumulators because they do not exhibit more than $100 \mu \mathrm{g} \mathrm{g}^{-1}$ of Se in their dry mass when grown in seleniferous soils (Terry et al., 2000). On the other hand, a selected group of plants (e.g., species of the genera Astragalus, Xylorrhiza, Stanleyea, Allium, and Brassica) may exhibit from hundreds until thousands of micrograms of Se by grams of dry mass when grown in Se-enriched soils, being these crops classified in Se accumulators and hyperaccumulators (Terry et al., 2000; Pilon-Smits and Quinn, 2010; FairweatherTait et al., 2011). Non-accumulators accumulate Se preferentially as selenomethionine while accumulators and hyperaccumulators present considerable accumulation of methylated organic Se forms (Fairweather-Tait et al., 2010; Ávila et al., 2014). It was previously found that Se-enriched broccolis have considerable contents of $\mathrm{Se}$ methylselenocysteine in sprout and floret tissues (Ávila et al., 2013).

One of the safest and most important way to increase Se intake is consuming Se-enriched foods, which is possible though crops with higher Se content in their edible parts. Therefore, aiming to increase the Se intake by population in Se-poor areas, the biofortification of staple crops with Se has a great relevance. Basically, biofortification is defined as a process to increase the nutritional values of crops in terms of essential nutrients for animal and human nutrition, such as vitamins, iron $(\mathrm{Fe})$, zinc $(\mathrm{Zn})$, iodine (I), and Se. The biofortification of crops with Se may be performed of different ways. Genetic biofortification involves the traditional and molecular plant breeding approaches to choose cultivars of a given specie that are efficient to accumulate Se. In addition, agronomic biofortification refers to the use of Se-containing fertilizers (applied to soil and/or by foliar spray) to increase contents of Se in staple plant foods. Genetic and agronomic biofortification of staple crops have been extensively studied and have showed to be good approaches to increase the natural intake of $\mathrm{Se}$ by animals and humans (Pilon-Smits and Quinn, 2010; Ramos et al., 2010; Fairweather-Tait et al., 2011; Ávila et al., 2013).

A good example of using fertilizers containing Se to increase the Se intake in foods and feeds has been currently observed in Finland. The low available Se contents in the Finnish soils result in an insufficient amount of Se intake by animals and humans. Hence, this country started to add Se in fertilizer since 1984 to reduce the occurrence of Se deficiency in the population, through a policy established by the Ministry of Agriculture and Forestry. Several studies have pointed out that the increased Se content in the edible parts of staple crops is closely linked with the decrease of health problems associated with Se deficiency, following the inclusion of Se into the fertilizers in Finland. The positive effects of adding Se in fertilizers to biofortify crop plants and to improve the health of the Finnish population may be seen with details in a publication elsewhere (Alfthan et al., 2015). 


\section{CURRENT AND FUTURE NEEDS}

As aforementioned the increase in Se intake by population with the use of Se-containing fertilizers in Finland has been well documented, being a satisfactory strategy to be performed in other countries where the natural Se content or availability in soils is low, such as in Brazil. In this context, it has to be mentioned that the Ministry of Agriculture, Livestock, and Supply included Se as a possible micronutrient to be added in Brazilian fertilizers, according the Normative Instruction number 46 recently published (BRAZIL, 2016).

However, such action of applying fertilizers with Se needs to be carried out with caution, taking into account that the dose range of dietary Se requirement for humans is narrow. Therefore, soil characteristics that affect $\mathrm{Se}$ availability, such as interactions with other elements and sorption-desorption reactions with minerals and organic matter, need to be well understood. Such knowledge will assist to establish forms and doses of Se to be added in fertilizers as an important way to improve the Se intake by population in Se-poor sites. Moreover, it will necessary to build up a monitoring plan to assess contents of Se in soils and in agricultural crops, as well as in the human body, to regulate further adjustments, avoiding excessive Se intake by population (i.e, Se intake rise more than the nutritional recommendations for humans).

\section{ACKNOWLEDGMENTS}

The authors would like to thank the National Council for Scientific and Technological Development (CNPq), the Minas Gerais State Foundation (FAPEMIG), and the Coordination for the Improvement of Higher Education Personnel (CAPES) for financial support.

\section{REFERENCES}

ABREU, L. de et al. Sorção de selênio em solos do bioma Cerrado. Revista Brasileira de Ciência do Solo, 35:19952003, 2011.

ALDOSARY, B. M. et al. Case series of selenium toxicity from a nutritional supplement. Clinical Toxicology, 50(1):57-64, 2012.

ALFTHAN, G. et al. Effects of nationwide addition of selenium to fertilizers on foods, and animal and human health in Finland: From deficiency to optimal selenium status of the population. Journal of Trace Elements in Medicine and Biology, 31:142-147, 2015.

ÁVILA, F. W. et al. Impact of selenium supply on Semethylselenocysteine and glucosinolate accumulation in selenium-biofortified Brassica sprouts. Food Chemistry, 165:578-586, 2014.

ÁVILA, F. W. et al. Assessment of the anticancer compounds Semethylselenocysteine and glucosinolates in Se-biofortified broccoli (Brassica oleracea L. var. italica) sprouts and florets. Journal of Agricultural and Food Chemistry, 61:62166223, 2013.

BAJAJ, M. et al. Hazardous concentrations of selenium in soil and groundwater in North-West India. Journal of Hazardous Materials, 189: 640-646, 2011.

BARCELOUX, D. Selenium. Journal of Toxicology - Clinical Toxicology, 37(2):311-312, 1999.

BENDICH, A. Dietary reference intakes for vitamin C, vitamin E, selenium, and carotenoids. Journal of Nutrition, Philadelphia, 17(4):364-365, 2001.

BRADFORD, G. R. et al. Background concentrations oftrace and major elements in California soils. Kearney Foundation Special Report, University of California, Riverside. 1996, 32p.

BRAZIL, Ministry of Agriculture, Livestock, and Supply. Normative Instruction $N^{\circ} 46,2016$. Available in: <http://www.lex.com.br/ legis_27238727_INSTRUCAO_NORMATIVA_N_46_DE_22_DE_ NOVEMBRO_DE_2016.aspx> Access in: July, 10, 2017.

CARDOSO, B. R. et al. Selenium, selenoproteins and neurodegenerative diseases. Metallomics, 7(8):12131228, 2015.

CHRISTOPHERSEN, O. A. et al. Selenium. In: ALLOWAY, B. J. Heavy Metals in Soils: Trace Metals and Metalloids in Soils and their Bioavailability. Environmental Pollution, 22:429-463, 2013.

CHEN, M.; MA, L. Q.; HARRIS, W. G. Baseline concentrations of 15 trace elements in Florida surface soils. Journal of Environmental Quality, 28:1173-1181, 1999.

COLEMAN, L.; BRAGG, L. J.; FINKELMAN, R. B. Distribution and mode of occurrence of selenium in US coals. Environmental geochemistry and health, 15(4):215-227, 1993.

COMBS, G. F. Food system-based approaches to improving micronutrient nutrition: The case for selenium. Biofactors, 12(1/4):39-43, 2000.

COMBS, G. F. Selenium in global food systems. British Journal of Nutrition, 85(5):517-547, 2001.

CONNOR, J. J.; SCHAKLETTE, H. Background geochemistry of some rocks, soils, plants, and vegetables in the conterminous United States. 1975. 168p. 
CRONIN, S. J. et al. Impact of Ruapehu ash fall on soil and pasture nutrient status 1. October 1995 eruptions. New Zealand Journal of Agricultural Research, 40(3):383395, 1997.

DAVIS, C. D.; TSUJI, P. A.; MILNER, J. A. Selenoproteins and cancer prevention. Annual review of nutrition, 32:73-95, 2012.

DONG, Y. et al. Characterization of the biological activity of y-glutamyl-Se-methylselenocysteine: A novel, naturally occurring anticancer agent from garlic. Cancer Research, 61(7):2923-2928, 2001.

EICHE, E. Microscale distribution and elemental associations of $\mathrm{Se}$ in seleniferous soils in Punjab, India. Environmental Science and Pollution Research, 22(7):5425-5436, 2015.

EICH-GREATOREX, S.; KROGSTAD, T.; SOGN, T. A. Effect of phosphorus status of the soil on selenium availability. Journal of Plant Nutrition and Soil Science, 173:337$344,2010$.

EL-RAMADY, H. R. et al. Selenium and nano-selenium in agroecosystems. Environmental Chemistry Letters, 12:495-510, 2014.

ELRASHIDI, M. A. et al. Chemical equilibria of selenium in soils: A theoretical development. Soil Science, 144:141, 1987.

FAIRWEATHER-TAIT, S. J. et al. Selenium in human health and disease. Antioxidants \& Redox Signaling, 14(7):13371383, 2011.

FAIRWEATHER-TAIT, S. J.; COLLINGS, R.; HURST, R. Selenium bioavailability: Current knowledge and future research requirements. The American Journal of Clinical Nutrition, 91(5):1484S-1491S, 2010.

FERREIRA, K. S. et al. Concentrações de selênio em alimentos consumidos no Brasil. Revista Panamericana de Salud Publica, 11(3):172-177, 2002.

FINLEY, J. W. Bioavailability of selenium from foods. Nutrition Reviews, 64(3):146-151, 2006.

FLOOR, G. H.; IGLESIAS, M.; ROMAN-ROSS, G. Selenium determination in volcanic soils by ICP-QMS: Influence of reaction cell pressurization and methanol addition on the occurrence of spectral interferences. Journal of Analytical Atomic Spectrometry, 24(7):944-948, 2009.

FLOOR, G. H.; ROMÁN-ROSS, G. Selenium in volcanic environments: A review. Applied Geochemistry, 27(3):517531, 2012.
FORDYCE, F. M. et al. An initial study to assess the use of geological parent materials to predict the Se concentration in overlying soils and in five staple foodstuffs produced on them in Scotland. Science of the Total Environment, 408:5295-5305, 2010.

FORDYCE, F. Selenium Geochemistry and Health. AMBIO: A Journal of the Human Environment, 36(1):94-97, 2007.

FORDYCE, F. Selenium. SELINUS, O. et al. (Eds.). Essentials of Medical Geology, Academic Press, p.373-415, 2005.

GABOS, M. B.; ALLEONI, L. R. F.; ABREU, C. A. Background levels of selenium in some selected Brazilian tropical soils. Journal of Geochemical Exploration, 145:35-39, 2014 a.

GABOS, M. B.; GOLDBERG, S.; ALLEONI, L. R. F. Modeling selenium (IV and VI) adsorption envelopes in selected tropical using the constant capacitance model. Environmental Toxicology and Chemistry, 9999:1-11, 2014b.

GOLDHABER, S. B. Trace element risk assessment: Essentiality vs. toxicity. Regulatory Toxicology and Pharmacology, 38(2):232-242, 2003.

IP, C. et al. In vitro and in vivo studies of methylseleninic acid: Evidence that a monomethylated selenium metabolite is critical for cancer chemoprevention. Cancer Research, 60(11):2882-2886, 2000.

IP, C.; GANTHER, H. E. Activity of methylated forms of selenium in cancer prevention. Cancer Research, 50(4):1206-1211, 1990.

JORDAN, N. et al. Adsorption mechanism of selenium (VI) into maghemite. Geochimica et Cosmochimica Acta, 103:63-75, 2013.

KABATA-PENDIAS, A. Trace elements in soils and plants. Taylor and Francis Group, 4th ed., Boca Raton, 2011. 505p.

KELLY, S. D.; HESTERBERG, D.; RAVEL, B. Analysis of soils and minerals using X-ray absorption spectroscopy. In: ULERY, A. L.; DREES, L. R. Methods of soil analysis, part 5 mineralogical methods. Soil Science Society of America, Madison, WI, USA, 2008. p.387-464.

LABUNSKYY, V. M.; HATFIELD, D. L.; GLADYSHEV, V. N. Selenoproteins: Molecular pathways and physiological roles. Physiological Reviews, 94(3):739-777, 2014.

LEE, S. O. et al. Monomethylated selenium inhibits growth of LNCaP human prostate cancer xenograft accompanied by a decrease in the expression of androgen receptor and prostate-specific antigen (PSA). Prostate, 66(10):10701075, 2006. 
LENZ, M.; LENS, P. N. The essential toxin: The changing perception of selenium in environmental sciences. Science of the Total Environment, 407(12):3620-3633, 2009.

LESSA, J. H. L. et al. Adsorption-desorption reactions of selenium (VI) in tropical cultivated and uncultivated soils under Cerrado bioma. Chemosphere, 164:271-277, 2016.

$\mathrm{LI}, \mathrm{H}$. et al. Selenium speciation in soil and rice: Influence of water management and Se fertilization. Journal of Agricultural and Food Chemistry, 58:11837-11843, 2010.

MAIHARA, V. A. et al. Daily dietary selenium intake of selected Brazilian population groups. Journal of Radioanalytical and Nuclear Chemistry, 259(3):465-468, 2004.

MARTENS, D. A.; SUAREZ, D. L. Selenium speciation of soil/ sediment determined with sequential extractions and hydride generation atomic absorption spectrophotometty. Environmental Science and Technology, 31:133-139, 1997.

MATOS, R. P. et al. Correlation between the natural levels of selenium and soil physicochemical characteristics from the Jequitinhonha Valley (MG), Brazil. Journal of Geochemical Exploration, 172:195-202, 2017.

McBRIDE, M. B. Environmental chemistry of soils. Oxford University Press, New York, 1994, 416p.

MEDINA, D. et al. Se-methylselenocysteine: A new compound for chemoprevention of breast cancer. Nutrition and Cancer-an International Journal, 40(1):12-17, 2001.

MEHDI, Y. et al. Selenium in the environment, metabolism and involvement in body functions. Molecules, 18(3):32923311, 2013.

MILLER, D. D.; WELCH, R. M. Food system strategies for preventing micronutrient malnutrition. Food Policy, 42:115-128, 2013.

MONTEIL-RIVERA, F. et al. Sorption of selenite $\left(\mathrm{SeO}_{3}{ }^{2-}\right)$ on hydroxyapatite: An exchange process. Journal of Colloids and Interface Science, 221:291-300, 2000.

MORRIS, J. S.; CRANE, S. B. Selenium toxicity from a misformulated dietary supplement, adverse health effects, and the temporal response in the nail biologic monitor. Nutrients, 5(4):1024-1057, 2013.

MOUTA, E. R. et al. Adsorção de selênio em Latossolos. Revista Brasileira de Ciência do Solo, 32:1033-1041, 2008.

NAKAMARU, Y. M.; ALTANSUVD, J. Speciation and bioavailability of selenium and antimony in non-flooded and wetland soils: A review. Chemosphere, 111:366-371, 2014.
NAKAMARU, Y. M.; SEKINE, K. Sorption behavior of selenium and antimony in soils as a function of phosphate ion concentration. Soil Science and Plant Nutrition, 54(3):332-341, 2008.

NAKAMARU, Y.; TAGAMI, K.; UCHIDA, S. Effect of phosphate addition on the sorption-desorption reaction of selenium in Japonese agricultural soils. Chemosphere, 63:109-115, 2006.

ØGAARD, A. F.; SOGN, T. A.; EICH-GREATOREX, S. Effect of cattle manure on selenate and selenite retention in soil. Nutrient Cycling in Agroecosystems, 76:39-48, 2006.

OLIVER, M. A.; GREGORY, P. J. Soil, food security and human health: A review. European Journal of Soil Science, 66(2):257-276, 2015.

PEAK, D.; SPARKS, D. L. Mechanisms of selenate adsorption on iron oxides and hydroxides. Environmental Science and Technology, 36:1460-1466, 2002.

PÉREZ-SIRVENT, C. et al. Selenium content in soils from Murcia region (SE, Spain). Journal of Geochemical Exploration, 107:100-109, 2010.

PIETINEN, P. et al. Nutrition policy in Finland. Public Health Nutrition, 13(6A):901-906, 2010.

PILON-SMITS, E. A. H.; QUINN, C. F. Selenium metabolism in plants. In: HELL, R.; MENDEL, R. R. (Ed.). Cell biology of metals and nutrients. Heidelberg: Plant Cell Monographs, 2010. p.225-241.

QIN, H. B.; ZHU, J. M.; SU, H. Selenium fractions in organic matter from Se-rich soils and weathered stone coal in selenosis areas of China. Chemosphere, 86(6):626-633, 2012.

RAHMAN, M. M. et al. Selenium biofortification in lentil (Lens culinaris Medikus subsp. culinaris): Farmers' field survey and genotype $x$ environment effect. Food Research International, 54(2):1596-1604, 2013.

RAMOS, S. J. et al. Selenium biofortification and antioxidant activity in lettuce plants fed with selenate and selenite. Plant Soil and Environment, 56(12):584-588, 2010.

RAYMAN, M. P. Selenium and human health. The Lancet, 379(9822):1256-1268, 2012.

RAYMAN, M. P. The importance of selenium to human health. The Lancet, 356(9225):233-241, 2000.

RIAZ, M.; MEHMOOD, K. T. Selenium in human health and disease: A review. Journal of Postgraduate Medical Institute, 26(2):120-133, 2012. 
ROBBINS, C.; CARTER, D. Selenium concentrations in phosphorus fertilizer materials and associated uptake by plants. Soil Science Society of America Journal, 34(3):506$509,1970$.

RYAN, B.; DITTRICK, M. Selenium in the Mist Mountain formation of southeast British Columbia. British Columbia Ministry of Energy and Mines, Geological Fieldwork, p.2001-1, 2000.

RYAN-HARSHMAN, M.; ALDOORI, W. The relevance of selenium to immunity, cancer, and infectious/inflammatory diseases. Canadian Journal of Dietetic Practice and Research, 66(2):98-102, 2005.

SAEKI, K.; MATSUMOTO, S.; TATSUKAWA, R. Selenite adsorption by manganese oxides. Soil Science, 160:265-272, 1995

SAIKI, M. K.; JENNINGS, M. R.; BRUMBAUGH, W. G. Boron, molybdenum, and selenium in aquatic food chains from the lower San Joaquin River and its tributaries, California. Archives of Environmental Contamination and Toxicology, 24(3):307-319, 1993.

SCHWARZ, K.; FOLTZ, C. M. Selenium as an integral part of factor 3 against dietary necrotic liver degeneration. Journal of the American Chemical Society, 79(12):3292-3293, 1957.

SHAND, C. A. et al. Selenium concentrations in national inventory soils from Scotland and Sweden and their relationship with geochemical factors. Journal of Geochemical Exploration, 121(0):4-14, 2012.

SILLANPÄÄ, M.; JANSSON, H. Status of cadmium, lead, cobalt and selenium in soils and plants of thirty countries. Rome: FAO, 1992. 358p.

SPARKS, D. L. Environmental soil chemistry. London: 2ed. Academic Press, 2011. 352p.

SWANSON, C. A. et al. Selenium intake, age, gender, and smoking in relation to indices of selenium status of adults residing in a seleniferous area. The American Journal of Clinical Nutrition, 52(5):858-862, 1990.

TAN, J. A. et al. Selenium in soil and endemic diseases in China. Science of the Total Environment, 284(1/3):227-235, 2002.

TERMMERMAN, L. D. et al. Selenium content of Belgian cultivated soils and its uptake by field crops and vegetables. Science of the Total Environment, 468469:77-82, 2014.

TERRY, N. et al. Selenium in higher plants. Annual Review of Plant Physiology and Plant Molecular Biology, 51(1):401432, 2000.

THOMSON, C. D. Assessment of requirements for selenium and adequacy of selenium status: A review. European Journal of Clinical Nutrition, 58(3):391-402, 2004.

TOLU, J. et al. Distribution and speciation of ambient selenium in contrasted soils, from mineral to organic rich. Science of The Total Environment, 479-480(2014):93-101, 2014

VEATCH, A. E. et al. Selenium and nutrition: The accuracy and variability of the selenium content in commercial supplements. Journal of Radioanalytical and Nuclear Chemistry, 264(1):33-38, 2005.

VODYANITSKII, Y. N. Determination of the oxidation states of metals and metalloids: An analytical review. Eurasian Soil Science, 46:1139-1149, 2013.

WANG, L. et al. Methyl-selenium compounds inhibit prostate carcinogenesis in the transgenic adenocarcinoma of mouse prostate model with survival benefit. Cancer Prevention Research, 2(5):484-495, 2009.

WHITE, P. J.; BROADLEY, M. R. Biofortification of crops with seven mineral elements often lacking in human diets-iron, zinc, copper, calcium, magnesium, selenium and iodine. New Phytologist, 182(1):49-84, 2009.

WHO - World Health Organization. Environmental Health Criteria-58, Selenium. WHO Publishing, Geneva. 1987.

YAMADA, $H$. et al. Total selenium content of agricultural soils in Japan. Soil Science and Plant Nutrition, 55:616-622, 2009.

YANG, G. Q. et al. Endemic selenium intoxication of humans in China. American Journal of Clinical Nutrition, 37(5):872881, 1983.

YASIN, M. et al. Microbial-enhanced selenium and iron biofortification of wheat (Triticum aestivum L.) - Applications in phytoremediation and biofortification. International Journal of Phytoremediation, 17(4):341-347, 2015.

ZHANG, H. H. et al. Spatial distributions and potential risk analysis of total soil selenium in Guangdong Province, China. Journal of Environmental Quality, 37:780-787, 2008. 